\title{
ON SOME DEVELOPMENTS OF THE MAMMALIAN PRENASAL CARTILAGE.
}

\author{
By R. Broom, M.D., C.M., B.Sc.
}

\section{(Plate xuIv.)}

The prenasal element has been shown by Kitchen Parker* to be a median cartilaginous development found in the anterior part of the head and arising in connection with the front part of the cranial trabeculæ. Though this element is represented in all the groups from the Elasmobranchs to Mammals, in the majority of forms it is either rudimentary or only found in the young, and in the adult it rarely attains any great degree of development.

In the Elasmobranchs the prenasal cartilage is a well-developed structure, and forms the axis of the large rostrum in the Skate and other fishes. The rudimentary prenasal found in most higher forms is probably an inheritance from these cartilaginous fishes.

In the bony fishes with the development of the premaxillary bones an agent was provided which served the double purpose of cutting the water and of giving a firm support for the teeth, and the need for the prenasal being thus gone we find it reduced to a mere rudiment.

The premaxillary bones in almost all the higher forms with their important tooth-bearing function prevent the development of the prenasal cartilage, which though sometimes an element of importance in the very young animal, in most cases becomes obliterated by the developing premaxillaries.

In birds the prenasal forms the framework of the beak in the early embryo, but as development advances it gradually becomes encroached upon by the premaxillaries on either side. In the

* W. K. Parker. Various Monographs on Development of the Skull, Phil. Trans. 
skull of an embryo chick of the middle of the second week as figured by Parker,* the prenasal is seen as a well-developed median cartilage, passing to the front of the beak and separating the two premaxillaries from each other. In the chick two days old the premaxillaries have united and quite obliterated the prenasal in front, reducing it to a small median spur extending in front of the nasal septum and lying on the palatal surface of the hinder part of the united premaxillaries. In the old bird the cartilage has quite disappeared.

In the mammalia where the premaxillaries are generally well developed to support the incisor teeth, the prenasal cartilage is, as might be supposed, usually rudimentary or absent. There is moreover in most mammals another peculiarity unfavourable to the existence of the prenasal - the union of the prevomer with the premaxillary. As I have recently shown, $\uparrow$ the mammalian prevomer, though occasionally a distinct element (Ornithorhynchus, Miniopterus), usually early anchyloses with the premaxillary or becomes ossified in connection with it. As this structure lies below the nasal septum, in being connected anteriorly with the premaxillary, the anterior palatal region becomes to a large extent shut off from the nasal septum, and in the adult condition where the bones are closely articulated in the middle line completely so. In a few interesting instances, however, the prenasal element has succeeded in asserting itself.

The most remarkable developments of the prenasal are in the egg-laying mammals-Ornithorhynchus and Echidna. The premaxillaries in both these forms are edentulous and feebly developed, and in neither are they provided with palatine processes, as in Ornithorhynchus the prevomer is distinct and in Echidna quite absent.

* W. K. Parker. On the Structure and Development of the Skull of the Common Fowl. Phil. Trans. 1869, p. 755.

+ R. Broom. "On the Homology of the Palatine Process of the Manimalian Premaxillary." Proc. Linn. Soc. N.S.W. (2nd Ser.) Vol. x. 1895. 
In a recent paper* Wilson and Martin have carefully described some of the chief points in the anatomy of the muzzle of Ornithorhynchus. They have dealt principally with the structure and relations of the large rostral cartilage. By a series of transverse vertical sections the authors show that the nasal septum on passing forward divides into a slender upper and a well developed lower part, and that this latter being continued forward, broadens out and becomes the rostral cartilage. For a short distance the rostral cartilage is shown to be clasped between the premaxillaries, recalling the condition of the embryonic bird. From this relationship and from the fact of its being a continuation of the nasal septum, the rostral cartilage is held to be an enormously developed prenasal. With their view I must express my entire agreement. While my researches confirm the accuracy of the sections figured by Wilson and Martin, they reveal an interesting point apparently not observed by these authors. The rostral cartilage does not extend forward to the front of the beak as an entire sheet. Almost immediately in front of the plane passing through the anterior parts of the premaxillaries the cartilage becomes abruptly arrested in the middle line; but while this is so, the lateral parts extend forward almost to the front of the beak, where they again approach each other, meeting, or almost so, in the middle line. There is thus left in the middle an oval space entirely free from cartilage. This arrangement I have found in three different individuals (two males and one female). The lateral portions of the cartilage curve round backwards along the outer sides of the rostral crura, supporting the lip as shown by Wilson and Martin. It seems probable that this whole complicated marginal cartilage is a development of the prenasal, for though in the Skate the prenasal rostrum supports a pair of labials at its anterior part, in the higher forms when labial cartilages are present they never seem to have the same relations to the premaxillaries as is found in the Platypus.

* J. T. Wilson and C. J. Martin. "Observations upon the Anatomy of the Muzzle of Ornithorhynchus." Macleay Memorial Volume, Linn. Soc. N.S.W. 1893. 
In fig. 1, Pl. xliv., is represented a longitudinal median section of the snout of Ornithorhynchus which shows the relations of the cartilages. The nasal septum proper (n.s.) is seen in front to divide into the upper delicate cartilaginous process (a.n.s.) and the lower well developed prenasal (p.n.). The upper process passes between the anterior nares, whose position is indicated by the dotted lines (a.n.), and is probably the homologue of the anterior part of the nasal septum in the higher mammals, as to it are attached, in its hinder part at least, the alinasals. Though in the region of the anterior nares it is considerably removed from the prenasal plate, on passing forward it approaches the latter, and ends in close connection with it, at the point where the prenasal becomes arrested in the middle line. This point (marked ${ }^{*}$ ) probably represents the anterior end of the beak in the ancestor of the Platypus, as not only do the two cartilages here end together, but this is practically where the two premaxillaries would meet if they came together. Connected with i moreover, there is a further feature of importance. On the upper side of the beak in the middle line is a small area of thickened epithelium (c) unlike that of the rest of the beak. This is probably the remains of the caruncle. If it be so, and it is quite perceptible externally in the fresh specimen even to the naked eye, it corrects the statement of Owen's* that no trace of the caruncle can be found in the adult. Whatever be its signification, it is evidently closely related to the supposed apical point of the primitive beak, as a series of fibrous bands pass from it to the latter.

In the anterior part of the section is seen the anterior union of the incurving lateral portions $\left(p n^{\prime}\right)$, and between this and the supposed apical point the cartilage is seen to be absent.

The same section illustrates a few other points of interest. The prevomer or dumbbell-shaped bone (P.vo.) is seen cut longitudinally. Immediately in front of it Jacobson's cartilage (J.c.) may be noticed at the place where towards the anterior part of the organ the cartilages meet in the middle line. Behind the

* R. Owen. "Monotremata." Todd's Cyclop. Anat. and Phys. 
prevomer a small piece of cartilage is seen cut across (S.c.). This is Stenson's cartilage at the place where near the posterior part of Jacobson's organ it passes below the organ and meets its fellow of the other side. Behind this are seen the maxillary and the romer, and between this latter and the prevomer the large internarial opening recently described by Prof. Wilson.*

In the near ally of the Platypus - the Echidna-the condition of the prenasal illustrates the Monotreme type in a much less specialised form. Here we have a closer approach to the condition in the bird. In fig. 2, Pl. xLIV., is represented a median longitudinal section of the anterior part of the snout. The nasal septum (n.s.) closely resembles that in Ornithorhynchus, and like it divides into a small upper part (a.n.s.) and a larger lower - the prenasal $(p . n$.$) . The upper, as in the Platypus, supports the$ alinasals, but instead of passing straight forward, at its anterior part it becomes folded back and rests on the symphysis of the premaxillaries. In the very young specimens as figured by Newton Parker $\dagger$ the prenasal is well developed and bears much resemblance to that in Ornithorhynchus. As the animal reaches maturity the prenasal, however, becomes reduced by the developing premaxillaries into a thin plate of hyaline cartilage lying between the adjacent parts of the two bones. In old specimens the hyaline cartilage becomes partly ossified and partly converted into fibro-cartilage, only a little of the original tissue remaining. There is no apparent anterior extension of the prenasal comparable to that in Ornithorhynchus.

As has been already remarked in the higher forms, the prenasal is usually aborted by the great development of the premaxillaries. In the Australian Bat (Miniopterus schreibersii, Natt.), however, as the premaxillaries do not meet in the middle line, we have

* J. T. Wilson. "Observations upon the anatomy and relations of the Dumbbell-shaped Bone in Ornithorhynchus, \&c." Proc. Linn. Snc. N.S.W. (2nd Ser.) Vol. ix. 1894.

† W. N. Parker. "On some points in the Structure of the Young of Echidna aculeata." Proc. Zool. Soc. 1894. 
here an opportunity of seeing the uncomplicated higher mammalian condition, and though the bat is high in the scale of organisation it will thus be well to consider it first. If a transverse vertical section be made in the plane which passes through the opening of Jacobson's organ into Stenson's duct there is seen (fig. 4) a delicate nasal septum (n.s.) which does not reach the level of the nasal floor, with on either side of its base the usual cartilages of the nasal floor (n.f.c.), here distinct from the alinasals. Inferiorly Stenson's ducts (n.p.c.) are seen passing up from the palate with between them the papilla. Round the upper part of the duct is a sickle-shaped piece of cartilage whose inner part, surrounding what is practically the anterior part of Jacobson's organ, is the anterior continuation of Jacobson's cartilage, and the outer part of which is the similar continuation of Stenson's cartilage. Between the portions representing Jacobson's cartilage is found a small median mass (p.n.) which from its relations may almost certainly be regarded as the prenasal. Posteriorly this cartilage has no connection with the nasal septum, but it oceupies a position somewhat similar to that of the prenasal in the foetal calf (fig. 7). A very little in front of this plane the small prenasal is seen sending downwards two lateral plates which pass one to each side of the papilla and thus forming its framework (p.n. fig. 5). There is no further anterior extension. Though the downward lateral processes can hardly be homologous with the lateral extensions of the prenasal in Orniihorhynchus, they illustrate potentialities of the structure usually latent. The condition is, however, specially interesting as throwing light on the peculiar structures found in the Marsupials.

In both Diprotodont and Polyprotodont Marsupials there is in the anterior part of the palate an unusually well marked papilla which generally separates the naso-palatine ducts considerably. It is remarkably developed in the Wombat and very well in the Phalangers. In all the forms I have examined (Macropus, Trichosurus, Dasyurus and Perameles) this papilla is supported by a cartilaginous plate. In the adult T'richosurus there is a median ridge from which lateral plates pass off. Here and there the 
lateral portions are detached or perforated, as if the whole plate were fundamentally a median structure with lateral expansions. In fig. 6 is represented a transverse vertical section of the snout of the Bandicoot (Perameles nasuta) in the plane of the anterior part of Jacobson's Organ. Here there is no distinct ridge in the middle line, and the plate is moderately uniform in thickness. This papillary cartilage has no direct connection with any other cartilage. In fig. 3 is shown a median longitudinal section of the nasal region of a pouch specimen of the common Phalanger ('Trichosurus vulpecula, Kerr), illustrating the relations of the small papillary cartilage (p.c.). The premaxillary $(P m x)$ is seen united with the prevomer which forms its palatine process $(p \cdot \operatorname{Pm} x)$ : a dotted line indicates the limits of the different elements as observed in sections slightly out of the mesial plane. The posterior end is found situated near the posterior border of the symphysis of the premaxillary proper, as if it were shut off from its proper relations by the union of the premaxillary with the prevomer. When fig. 6 is compared with fig. 5 representing the condition in the Bat the resemblance between the cartilages of the papillæ is most striking; the only important difference is that in the Marsupial the upper portion representing the prenasal proper is lost. While thus we have in the Bat a prenasal cartilage which gives rise to a support for the papilla, in the Marsupial we have the remains of a similar development, only the papillary portion being left.

In Klein's* paper on the Organ of Jacobson in the Guinea Pig in referring to the relations of Stenson's ducts near their palatal opening he calls attention to "a smaller or larger apparently isolated nodule of cartilage found between the two ducts." This he regards as a detached portion of Stenson's cartilage, but in view of this condition in Marsupials and the Bat I think not improbable that it may be the rudiment of a prenasal development.

Fig. 7 represents a section of the nose of a 6 -inch fœtal calf. Here the prenasal is well developed and passes between the premaxillaries. This condition shows the connection between the

* Q.J.M.S. Vol. xxi. (1881), p. 229. 
Monotreme type on the one hand and that of the Bat on the other, while by contrasting figures $7,4,5$ and 6 the nature of the Bat and Marsupial developments becomes manifest.

My best thanks are due to Mr. A. G. Hamilton for the specimen of bandicoot examined, and to Prof. Wilson and Mr. J. J. Fletcher for other kind assistance.

\section{EXPLANATION OF FIGURES.}

Plate XLIV.

\section{Reference Letters.}

a.n., anterior nares-relative position indicated by dotted lines; a.n.s., anterior portion of nasal septum; c., supposed remnant of caruncle; Fr., frontal; i.n.p., internasal passage; J.c., Jacobson's cartilage; J.o., Jacobson's organ; $M x$., maxillary; $N a$., nasal; n.f.c., nasal-floor cartilage; n.p.c., naso-palatine canal; n.s., nasal septum; p.c., papillary cartilage; $P m x$, premaxillary; $p . n$., prenasal cartilage; $p . n^{\prime}$. , prenasal at its anterior part; p.Pmx., palatine process of the premaxillary; P.Vo., prevomer; S.c., Stenson's cartilage; Vo., vomer; v.s., vascular spaces; *, supposed apical point of primitive beak in Platypus; + , a small detached piece of cartilage of doubtful signification.

Fig. 1.--Longitudinal median section of the snout of Ornithorhynchus $(\times 5)$.

Fig. 2.-Longitudinal median section of the snout of Echidna ( $\times$ 5).

Fig. 3.-Longitudinal median section of head of 4-in. mammary fotus of common Phalanger (Trichosurus vulpecula) $(\times 4)$.

Fig. 4.-Transverse vertical section of portion of nose of Australian Bat (Miniopterus schreibersii, Natt.) in the region of the outlet of Jacobson's organ $(\times 45)$.

Fig. 5.-Transverse vertical section of portion of nose of Australian Bat (Miniopterus schreibersii, Natt.) near the front of Stenson's duct $(\times 45)$.

Fig. 6.-Transverse vertical section of portion of nose of the Bandicoot (Perameles nasuta) in region of the anterior part of Jacobson's organ $(\times 12)$.

Fig. 7.-Transverse rertical section of portion of nose of 6 -in. fæetal calf $(\times 6)$. 


\section{$2 \mathrm{BHL}$ Biodiversity Heritage Library}

Broom, Robert. 1896. "On some developments of the mammalian prenasal cartilage." Proceedings of the Linnean Society of New South Wales 10, 555-562. https://doi.org/10.5962/bhl.part.24368.

View This Item Online: $\underline{\text { https://www.biodiversitylibrary.org/item/30097 }}$

DOI: https://doi.org/10.5962/bhl.part.24368

Permalink: https://www.biodiversitylibrary.org/partpdf/24368

\section{Holding Institution}

MBLWHOI Library

\section{Sponsored by}

MBLWHOI Library

\section{Copyright \& Reuse}

Copyright Status: NOT_IN_COPYRIGHT

This document was created from content at the Biodiversity Heritage Library, the world's largest open access digital library for biodiversity literature and archives. Visit BHL at https://www.biodiversitylibrary.org. 